\title{
Re-Location: Urban and architectural analysis of resettlement practices in the brown coal mining area of Welzow-Süd in East Germany
}

\author{
Julia Ess ${ }^{1,1}$ \\ ${ }^{1}$ Brandenburg University of Technology (BTU) Cottbus-Senftenberg, Faculty of Architecture, Civil \\ Engineering and Urban Planning, Chair of History of Architecture, DFG Research Training Group \\ 1913, "Cultural and Technological Significance of Historic Buildings", 03013 Cottbus, Germany
}

\begin{abstract}
Since the beginning of the $20^{\text {th }}$ century, more than 370 villages with a total amount of about 120,000 inhabitants have been relocated in Germany due to open-pit lignite mining. The devastation of villages and resettlement of their inhabitants had and still have massive implications on the rural landscape and settlement structure of the region. The planning of the relocations reflects, to a great extent, social, economic, and political change in post-war Germany, as well as development in town planning and architectural concepts. The paper focuses on the resettlements that took place due to the surface mine of Welzow-Süd (Lusatia, southern Brandenburg), where the development of the resettlement practices of the GDR since the late 1960s and after reunification up until today can be studied in one single open-pit mine.
\end{abstract}

\section{Introduction}

Since the beginning of the $20^{\text {th }}$ century, more than 370 villages with a total amount of about 120,000 inhabitants have been relocated in Germany due to open-pit lignite mining. The planning of the relocations reflects, to a great extent, social, economic, and political change in post-war Germany, as well as development in town planning and architectural concepts.

\section{Research topic}

In this paper, I argue that in the socialist-centralized system of the German Democratic Republic (GDR) the dissolution of rural communities and group relocations corresponding to the political agenda and modern visions of the time were common, while in the democratic system of West Germany collective resettlements were already implemented in the 1950s. In the years following reunification, the resettlement practices in the Rhineland acted as a prototype for those in Lusatia. By the mid-1990s, across Germany, collective resettlements were undertaken.

\footnotetext{
${ }^{1}$ Corresponding author: julia.ess@b-tu.de
} 
This paper focuses on the resettlements as a result of the operations of the opencast mine of Welzow-Süd (Lusatia, southern Brandenburg), which witnessed the development of the resettlement practices from the GDR period from the late 1960s and after reunification up to today. The villages will be briefly described, and the implications of the devastation of these villages and the resettlement of their inhabitants on the rural landscape and settlement structure of the region will be discussed ${ }^{2}$.

\section{Current state of research}

Important references on the lignite-induced devastation of villages in Lusatia include those of Frank Förster and the Archiv verschwundener Orte (AvO, Archive of vanished villages) in Forst-Horno [1, 2]. The first comprehensive publication on lignite-induced resettlement in all of Germany was released by the Academy for Spatial Research and Planning [3].

Studies of the planning history of lignite-induced resettlements primarily deal with resettlements in the Rhineland. Comparisons of resettlement concepts across Germany sometimes neglect the GDR resettlements -by either not going into detail or skipping those decades completely ${ }^{3}$.

A comprehensive, scientifically compiled study on the resettlement practices in the GDR that goes beyond a few lines or references in a footnote, does not exist. This most interesting and fascinating omission needs to be addressed and will be tackled in my research which aims to identify and elaborate the different resettlement concepts that were applied in the GDR over the decades and to describe the development of the GDR resettlement policy.

\section{Research questions}

The following key questions define the research area:

- How did the respective political, economic and social circumstances influence resettlement planning?

- When can the turnaround in the GDR planning be observed? What impacts are associated with it? What happened after reunification?

\section{Procedure and methods}

Research data was collected through the search of archival sources and the study of secondary literature. In the case of the village of Wolkenberg, the search of archival sources took place at the City Archive (Stadtarchiv, SA SPB) in Spremberg, the Archive of Vanished Villages (Archiv verschwundener Orte) in Forst/Lausitz, and the

\footnotetext{
${ }^{2}$ This case study is part of the author's ongoing dissertation research, which explores relocation strategies in surface coal mining areas of Germany with a focus on architecture and planning history in the GDR district of Cottbus, Lusatia. A comparison of the resettlement policies in the GDR and the FRG, which differed fundamentally and changed over the decades, will be put forth in the author's dissertation. Through the analysis of case studies of selected villages (or open-pit mining areas), the relocation concepts and influence of the respective political, economic, and social conditions will be examined and a typology of relocation strategies will be developed.

${ }^{3}$ In addition to the works mentioned above, many of the available publications on lignite-induced resettlements focus on socio-economic aspects, socio-cultural implications, or the development of the cultural landscape after mining (recultivation).
} 
Brandenburg Main State Archive (Brandenburgisches Landeshauptarchiv, BLHA) in Potsdam.

\section{Context: resettlement and lignite mining}

\section{Forced migration and forced displacement}

Forced migration is a current and relevant topic worldwide. Forced displacement includes demographic movements such as flight, evacuation, displacement, and resettlement, which have diverse causes including: [4]

- conflict-induced displacement: armed conflicts, (civil) war, generalized violence, and persecution on the grounds of nationality, race, religion, political opinion or social group.

- disaster-induced displacement: natural disasters (e.g. floods, earthquakes), environmental change (global warming: e.g. sea-level rise, desertification) and human-made disasters (industrial accidents, radioactivity)

- development-induced displacement: caused by mining actions and large-scale infrastructure projects like dams, roads, airports or military training grounds

In the GDR, in addition to the resettlements that took place due to the mining of lignite (in Lusatia and Central Germany) and uranium (in Wismut), resettlements were undertaken due to collectivization of agriculture and the establishment of agricultural production cooperatives ${ }^{4}$. Other forced displacements in the GDR were caused by the construction of the inner German border ${ }^{5}$. The focus of this paper, however, is on the resettlements caused by open-cast lignite mining in Lusatia.

\section{Relocation concepts}

Generally, one can distinguish four basic concepts of relocation practices that have been applied in the lignite mining areas of Germany: [5: 48, 6: 63, 7: 28, 8: 440]

- single relocation: single resettlers/families receive financial compensation payments to build or buy a new residence of their choice

- group relocation: integration of groups of resettlers in several villages or cities

- collective relocation: the affected population is collectively resettled in a new location; a new village develops

- consolidating relocation: inhabitants of numerous villages are resettled collectively in a new or existing village.

4 On the agricultural production cooperatives (LPGs - Landwirtschaftliche Produktionsgenossenschaften) see MODSCAPES Case Study "German Democratic Republic" by Friedrich Kuhlmann, Vittoria Capresi, and Christoph Muth at EMU and TU Berlin (http://casestudies/germany/).

${ }^{5}$ Along the border, authorities organized the resettlement of about 10,000 East German civilians in programs with codenames like "Operation Vermin" (Aktion Ungeziefer) in 1952. 

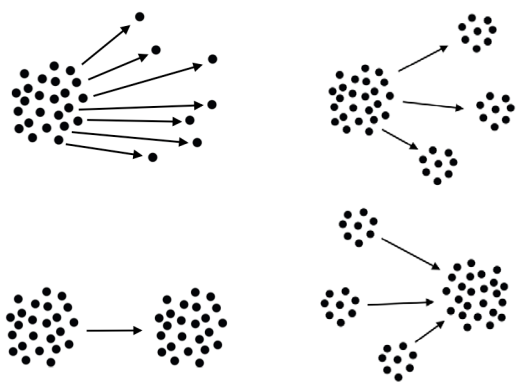

Fig. 1. Basic relocation concepts.

Top left: single relocation, top right: group relocation, bottom left: collective relocation, bottom right: consolidating relocation.

In the GDR, until the mid-1980s it was common to resettle displaced inhabitants via single and group relocations into new Plattenbau housing on the outskirts of cities, e.g. in the new development areas of Cottbus, Senftenberg, or Hoyerswerda. This was called Kohleersatzwohnungsbau, which literally means "the construction of coal substitution housing". Single and group resettlements appeared to be more costefficient than collective relocations to new villages. For many displaced persons, who had mainly lived in rural areas before, life in new urban areas did not comply with their accustomed lifestyles. Dissatisfaction grew and many resettlers disliked the applied relocation schemes. Starting in the mid-1980s, regulations that facilitated the resettlement of displaced persons into detached prefabricated houses were put into place ${ }^{6}$.

In the West German Rhineland, by contrast, the concept of collective relocation was used since the 1950s. Back then new villages were developed which were regarded as being exemplary, and whose model architecture and car-friendly urban framework corresponded to the modern visions of the time [5: 45, 8: 440].

In the first few years following reunification, the resettlement practices in the Rhineland acted as a prototype for those in Lusatia. Today, the concept of public participation, which includes the resettlers in every step of the planning process, is a central element of the collective, "socially responsible" relocations both in West and East Germany.

\section{Open-pit lignite mining in Lusatia and the GDR}

The industrial mining of brown coal in Lusatia started in the middle of the $19^{\text {th }}$ century. In the beginning of the $20^{\text {th }}$ century, the first large excavators were developed, and open-cast mining took on a new dimension. Huge areas were being stripped. Consequently, at first forests, agricultural land and single houses, and later, whole villages were devastated to access the lignite lying below. In 1924, Laubusch was the first village in Lusatia to be completely razed by open-cast mining (125 resettlers).

After World War II, in the GDR, the nationalization of the brown coal industry and increased energy demand brought on by industrial growth led to the expansion of lignite open-cast mines in the 1950s and an increase in devastation and forced displacement

${ }^{6}$ See: [3: 54-55, 5: 265-266, 9: 269, 10: 50, 11: 181, 12: 92-93].

Also: BLHA, 803 BfT Ctb 80. Beschluß zur komplexen Wahrnehmung der Verantwortung der örtlichen Staatsorgane und des BKK Senftenberg zur Vorbereitung und Durchführung der bergbaulichen Inanspruchnahme von Siedlungen im Bezirk Cottbus", 1988. 
[3: 1, 5: 19, 6: 65, 12: 89-91]. In the GDR, for the production of energy, brown coal was almost exclusively being used. Therefore, huge quantities of lignite were extracted. The district of Cottbus became the "centre of coal and energy for the GDR" [5: 262-263, 8: 439].

By the 1970 s, about $20 \%$ of the district's area was designated as mining reserve (Bergbauschutzgebiet). That meant not only that this area was determined to be used for mining purposes, but also that no more money was invested in infrastructure, and the construction of new buildings was no longer allowed [3: 53, 9: 262]. During GDRtimes alone, 71 villages and 30 neighbourhoods in Lusatia vanished from the map, and over 22,000 people were relocated. At this point, it should be noted, that this number is the official information in the records and should be viewed as a minimum number, as is does not account for resettlers who left villages before the official resettlement programme [1: 22]. The same is true for most of the figures given below, which have yet to be verified from archival sources.

\section{The Case study of Welzow-Süd}

A brief description of the open-cast mine of Welzow-Süd and the resettlements associated with it follows. The relocations of Wolkenberg and Dollan are presented in somewhat greater detail, since they stand at the "turning point" in the GDR's relocation policy, foreshadowing the political change known as Wende.

\section{The open-pit mine of Welzow-Süd and the "receiving" city of Spremberg}

Welzow-Süd is one of the largest mines in Germany in terms of agricultural, forested and inhabited area affected by devastation. The open-cast mine is located in the middle of the Cottbus-Senftenberg-Hoyerswerda triangle, just west of the city of Spremberg in the Lusatian lignite mining district of southern Brandenburg.

Small-scale underground and surface mining activities in the area of Welzow date back to the middle of the $19^{\text {th }}$ century. The large-scale Welzow-Süd open-cast mine opened in 1959 and is still active today, which presents an interesting time frame. Here, the development of the resettlement practices during GDR times from the late 1960s up to reunification and beyond can be studied in one single open-cast mine ${ }^{7}$.

From the 1960s to the 1980s, the town of Spremberg (c. 23.000 inhabitants in 2016, including incorporated villages) was the main town to take resettlers from the villages affected by the mine, as shown below. The resettlements played an important role in the urban development of the city ${ }^{8}$.

\footnotetext{
${ }^{7}$ During GDR times, the mine belonged to the publicly owned VEB Braunkohlenwerk Welzow (Brown Coal Company). After reunification in 1990, the mine was privatized and transformed into the Lausitzer Braunkohlen AG (LAUBAG, Lusatian Brown Coal Corporation). It was sold by the trust agency (Treuhand) in 1994 to a consortium of nine West Germany energy companies. At the time, the main shareholder of LAUBAG was Rheinbraun AG (Brown Coal Corporation of the Rhineland), which held 39,5\% of the company's shares. In 2003, the Swedish state-owned energy company Vattenfall acquired LAUBAG. Vattenfall sold its German lignite sector to the Czech energy group EPH in 2016. At the moment, EPH operates the Welzow-Süd mine under the brand Lausitz Energie Bergbau AG (LEAG, Lusatia Energy Company). [14: 6]

${ }^{8}$ In a twist of fate, some of the persons previously displaced by lignite mining had to be resettled, in recent years, due to East German urban redevelopment activities (Stadtumbau) and the demolition of prefabricated concrete apartment buildings (Plattenbau).
} 


\section{Devastated villages during GDR times}

Starting in the south-east of Welzow, the mine first moved toward the northeast, then in a counter-clockwise circular motion.

The first village devastated due to the Welzow-Süd mine was Gosda. In 1968/69, almost half of whose 130 inhabitants were moved to new apartment buildings in Spremberg (43\%). The others were moved to Haidemühl (12\%), Proschim (11\%), and Welzow $(2 \%)$, other towns in the county of Spremberg or Cottbus (16\%), and another $16 \%$ moved further away or to unknown locations.

The largest relocation caused by the Welzow-Süd mine took place in 1972/73 in preparation of the devastation of Jessen. Most of the 650 inhabitants were relocated to the "Georgenberg" and "Römmlergelände" housing complexes in Spremberg.

In 1975/76, the partial devastation of Pulsberg precipitated the relocation of 110 people (about a quarter of the village's inhabitants). Most of them were moved to the "Schomberg" and "Georgenberg" housing complexes in Spremberg.

The 209 inhabitants of Roitz and its Josephsbrunn neighbourhood were primarily relocated to the "Schomberg" housing complex in Spremberg (1977/78).

The devastation of Stradow triggered the resettlement of 320 people in 1983/84, mainly to the "Schomberg" housing complex in Spremberg. A few families were able to acquire detached houses in the city and county of Spremberg.

Another big relocation took place in 1984/85 for the destruction of the village of Groß Buckow. Most of the 547 registered resettlers were moved to the "Schomberg" housing complex in Spremberg.

The inhabitants of the villages of Radeweise (1986, 80 people), Straußdorf (1988, 90 people) and Klein Buckow (1987/88, 180 people) were largely resettled to the "Heinrichsfelder Allee" housing complex in Spremberg. (Data: [1], [2], SA SPB)

Table 1. Villages devastated due to Welzow-Süd mine during GDR times.

(Source: [1] and [2])

\begin{tabular}{|c|c|c|}
\hline Devastated village & Year of resettlement & Number of resettlers \\
\hline Gosda & $1968 / 69$ & 130 \\
\hline Jessen & $1972 / 73$ & 650 \\
\hline Pulsberg (partially) & $1975 / 76$ & 110 \\
\hline Roitz and Josephsbrunn & $1977 / 78$ & 209 \\
\hline Stradow & $1983 / 84$ & 320 \\
\hline Groß Buckow & $1984 / 85$ & 547 \\
\hline Radeweise & 1986 & 80 \\
\hline Straußdorf & 1988 & 90 \\
\hline Klein Buckow & $1987 / 88$ & 180 \\
\hline Dollan and Wolkenberg & $1988 / 89 \& 1991 / 92$ & 172 \\
\hline & & Total: 2,488 \\
\hline
\end{tabular}

As stated above, most of the resettlers were moved via single or group relocations to new housing complexes in the neighbouring city of Spremberg (Georgenberg, Schomberg, Heinrichsfelder Allee). Only a few families were able to buy or build a detached house, which constituted a difficult undertaking. Former homeowners, who did not want to move into an apartment building, received a compensatory payment for 
their house, but the size of the payment often proved insufficient for the purchase or construction of a new house [1:27].

\section{Wolkenberg and Dollan - a resettlement at the "turning point"}

The resettlement of the village of Wolkenberg (1991/92) and its Dollan neighbourhood (1988/89) poses a special case, since it took place at the time of political change known as Wende. The resettlements were planned during GDR times, but were carried out after reunification.

The council for the district of Cottbus (Rat des Bezirks Cottbus: Büro für Territorialplanung) and the county of Spremberg (Rat des Kreises Spremberg) were in charge of planning the resettlement. A so called Arbeitsgemeinschaft Umsiedlung (resettlement working group) had to solve all problems and fulfil all tasks concerning the resettlement ${ }^{9}$.

At a town hall meeting in 1982, the inhabitants of Wolkenberg were informed of the impending devastation and resettlement. In subsequent individual talks, each family was invited to express their desired relocation destination. Taking into account certain household characteristics (e.g. size of family, elderly people, young adults, engaged people, pregnant women) and the existing housing situation (e.g. home-owner, tenant), their needs for the new home were registered in housing requirement lists ${ }^{10}$.

It can be seen that in many cases older people (especially widows) were moved to apartment buildings suitable for the elderly, and young adults, previously residing with their parents, were able to move into their own apartments. Some residents seem to have left the village before the official resettlement programme began, and at some point, their names vanished from the official lists. Engaged people, newlyweds and/or families expecting another child were given bigger apartments. One might assume that in the case of lignite-induced resettlements, it was easier to get one's own apartment as a young adult compared to people or young couples in other towns who just wanted to move out of their parents' home ${ }^{11}$.

In 1984, three housing possibilities existed for the resettlers: flats in apartment buildings in new housing complexes, flats in two-story multi-family buildings, and prefabricated row-houses. In 1986 and 1987, new regulations were put into place that facilitated the resettlement of home owners into detached prefabricated houses ${ }^{12}$. The

\footnotetext{
${ }^{9}$ The working group was comprised of the chairpersons of the district, county, and city councils, the mayor of Wolkenberg, representatives of the mining company and others.

${ }^{10}$ These lists contained the old addresses, names, birthdates, jobs, and work addresses of the resettlers, as well as the apartment sizes that they were entitled to. It should be noted, that during the course of planning, some changes occurred due do birth, death, or marriage. This might be one of the reasons for the existence of differing figures in the literature. This should be taken into account in the examination of other resettlements.

${ }^{11}$ SA SPB: Rat der Gemeinde Wolkenberg: Sig. 3532: "Vorbereitung und Durchführung der Ortsverlegung Wolkenberg" (1984-1990); and Sig. 3538: "Protokollbuch Gemeinderats- und Gemeindevertretersitzungen Wolkenberg" (1981-1990).

${ }^{12}$ BLHA, 803 BfT Ctb 80: "Beschluss des Präsidiums des Ministerrates der DDR vom 27.1.1986 über Vorschläge für Maßnahmen zur staatlichen Unterstützung von Bürgern, die infolge der Tätigkeit des Braunkohlenbergbaus ihre selbstgenutzten persönlichen Eigenheime aufgeben müssen"; and "Beschluss des Präsidiums des Ministerrates der DDR vom 10.4.1987 über Vorschläge für präzisierte und weitere Maßnamen zur staatlichen Unterstützung von Bürgern der DDR, die infolge der Tätigkeit des Braunkohlenbergbaues ihre selbstgenutzten persönlichen Eigenheime aufgeben müssen".
} 
new guidelines had an immediate effect on the resettlement of Wolkenberg, as 27 of the 64 homeowners opted for the construction of a new home with state-aided funds 17 families more than prior to the new regulations.

Studies estimate numbers of resettlers between 149 and 172 [1: 357-363, 2: 188-189, 14]. About $80 \%$ of Wolkenberg's inhabitants were relocated to the city of Spremberg, the remaining $20 \%$ moved to surrounding villages and cities (Welzow, Cottbus).

Taking a closer look at the resettlements to Spremberg, it can be observed that half of the people moved into apartment buildings, and most of them moved into the new housing complexes of "Schomberg" (c.10\%) and "Wiesenweg" (c.25\%). The other half moved into new or existing detached or semi-detached houses. Almost a third moved to "Wolkenberger Weg", a street comprised of 20 prefabricated single-family-homes $\left(\right.$ LPC-Eigenheim mit Steildach type A, D, E or F ${ }^{13}$.

\section{Collective "socially responsible" resettlements after reunification}

In the course of political change, German reunification and Western democracy opened up possibilities for civil resistance. Demonstrations and protests started by citizens' initiatives of to-be-resettled villages took place and resulted in the re-evaluation of all designated resettlement in Lusatia in the early 1990s. Some villages could be excluded from the mining plans; in some of them, the resettlement had already started or was even finished (e.g. Dubrau, Pritzen, and Klingmühl). In the area of Welzow-Süd all planned resettlements stayed on the agenda, except for Neupetershain, which would have caused the resettlement of over 1,600 people [9: 270]. A significant change in resettlement practises is observable.

The first relocation planned and carried out completely after reunification was that of Kausche together with Klein Görigk in 1995/96, posing a model case. The so called "Kausche-Vertrag" (Kausche agreement), signed in 1993, marked a turn in resettlement practises and policy in East Germany. For the first time, a village in the area of WelzowSüd was actually moved to a newly built neighbourhood as a whole. A collective "socially responsible" resettlement, based on the West German model and adapted to local requirements, was conducted. Since then, the so called "Lausitzer Weg" (Lusatian Way) strategy serves as an exemplar for relocations in Lusatia [1: 31.

For the inhabitants of Kausche and Klein Görigk, a new neighbourhood in the village of Drebkau was built (north of Welzow-Süd, some $6 \mathrm{~km}$ from Kausche). Most of the 369 inhabitants of Kausche and Klein Görigk moved into 33 detached or semidetached houses (40 families) and 25 small apartment buildings (149 flats).

Most of the inhabitants (37 out of $41,90 \%$ ) of Geisendorf resettled into detached houses in the new neighbourhood of Neu-Geisendorf ("new Geisendorf") in the village of Neupetershain in 2001 (west of Welzow-Süd, around $2 \mathrm{~km}$ from Geisendorf). The manor house of Geisendorf is the only building that remained in its original location. It now stands at the edge of the recultivated open-cast mine.

The largest post-reunification relocation, and to date the last devastation of a village due to the Welzow-Süd mine, occurred in Haidemühl from 2004 to 2006. 580 out of 645 inhabitants (90\%) moved to the new neighbourhood of Neu-Haidemühl ("new Haidemühl", east of Welzow-Süd, about $15 \mathrm{~km}$ from Haidemühl) in Spremberg/Sellessen. In Neu-Haidemühl 85 detached houses, 176 flats in small

${ }^{13}$ See footnote 11. 
apartment buildings, and a variety of community buildings were constructed (Data: [1], [2]).

Table 2. Villages devastated due to Welzow-Süd mine after reunification.

(Source: [1] and [2])

\begin{tabular}{|c|c|c|}
\hline Devastated village & Year of resettlement & Number of resettlers \\
\hline Kausche & $1995 / 96$ & 350 \\
\hline Klein Görigk & $1995 / 96$ & 19 \\
\hline Sagrode & $2000 / 01$ & 2 \\
\hline Geisendorf & 2001 & 41 \\
\hline Haidemühl & $2004-06$ & 645 \\
\hline & & Total: $\mathbf{1 , 0 5 7}$ \\
\hline
\end{tabular}

\section{Conclusion}

Industrialization, lignite mining, the devastation of villages and the resettlement of their inhabitants had, and continue to have, massive implications on the rural landscape and the settlement structure of the region.

Before the mining of lignite, small villages and hamlets scattered between grasslands, fields, and forests characterized the rural landscape in the area of WelzowSüd. The industrialized extraction of lignite and the expansion of the mine completely changed the area's settlement structure [9: 259].

During GDR times, the territorial concentration of the population in cities and rural centres was spurred on by the political goals of modernization and urbanization by means of internal migration. It suited the urban-oriented redistribution strategies of the socialist system, whose economic and social policies aimed for a further development of the "advanced socialist society by constantly improving the material and cultural living standard of the people" [15: 109-110]. In both East and West Germany, authorities and planners considered resettlements as an opportunity to improve living conditions and infrastructure as well as to reorganize the settlement and territorial structure [5: 21 and 265-266, 12: 93].

As shown above, in the GDR it was common to resettle displaced inhabitants via single and group relocations into new Plattenbau housing on the outskirts of cities. Starting in the mid-1980s, regulations that facilitated the resettlement of displaced persons into detached prefabricated houses were put into place. In the years following reunification, the resettlement practices in the Rhineland acted as a prototype for those in Lusatia. Since then, both in West and East Germany collective, "socially responsible" relocations are being conducted.

\section{Acknowledgements}

This work is part of my ongoing dissertation research which is funded by the German Research Foundation (DFG) in the framework of the Research Training Group 1913, "Cultural and Technological Significance of Historic Buildings", at Brandenburg University of Technology (BTU) Cottbus-Senftenberg. Dissertation supervisor: Prof. Dr. Christoph Bernhardt, Leibniz Institute for Research on Society and Space in Erkner. 


\section{Short resume}

Julia Ess holds a Master in Architecture from the Technical University in Vienna, with an Erasmus semester at Università luav di Venezia. Since April 2017 she has been a research assistant and Ph.D. student at the Brandenburg University of Technology (BTU) in Cottbus-Senftenberg, Chair of History of Architecture. Research interests: Historical architectural and urban research, building and planning history of the GDR.

\section{References}

\section{Archives:}

- BLHA - Brandenburgisches Landeshauptarchiv, Potsdam [Brandenburg Main State Archive]

- $\quad$ SA SPB - Stadtarchiv Spremberg [City Archive of Spremberg]

1. FÖRSTER, F. 2014. Verschwundene Dörfer im Lausitzer Braunkohlenrevier [Lost Villages in the Brown Coal Mining Area of Lusatia], $3^{\text {rd }}$ edition, Bautzen, DomowinaVerlag.

2. AVO - ARCHIV VERSCHWUNDENER ORTE (ed.), 2010. Dokumentation bergbaubedingter Umsiedlungen [Documentation of Mining-induced Resettlements], Forst.

3. ARL - AKADEMIE FÜR RAUMFORSCHUNG UND LANDESPLANUNG (ed.), 2000. Braunkohlenplanung und Umsiedlungsproblematik in der Raumordnungsplanung Brandenburgs, Nordrhein-Westfalens, Sachsens und Sachsen-Anhalts [Brown Coal Planning and the Issue of Resettlements in the Regional Development Planning of Brandenburg, North Rhine-Westphalia, Saxony and Saxony-Anhalt], (Working Paper, Arbeitsmaterial / Akademie für Raumforschung und Landesplanung: $\mathrm{n}^{\circ}$ 265), Hannover, ARL. Retrieved from https://shop.arl-net.de/media/direct/pdf/am_265.pdf [available on 15 January 2019].

4. FMO - FORCED MIGRATION ONLINE, 2012. What is forced migration? [Online] Refugee Studies Centre, University of Oxford. Retrieved from: http://www.forcedmigration.org/about/whatisfm [available on 15 April 2018].

5. DICKMANN, F. 1996. Umsiedlungsatlas des Rheinischen Braunkohlereviers. Siedlungsform, Wohnen, Infrastruktur - Umsiedlungsmaßnahmen als Faktor kommunalen Strukturwandels [Atlas of Resettlements in the Brown Coal Mining Area of the Rhineland]. Köln/Bonn, Rheinland-Verlag/Habelt.

6. MAYERS, E.; LÖGTERS, C. 1986. "Entwicklungstendenzen in der Gestaltung von Umsiedlungsstandorten - Ein Stück Umsiedlungsgeschichte" ["Patterns in the Development of Relocation Sites - A Resettlement History"], Braunkohle Tagebautechnik, vol. 38, $\mathrm{n}^{\circ}$ 4: 63-75.

7. SCHMIDT, H. 1958. Umsiedlungen im Rheinischen Braunkohlenrevier [Resettlements in the Brown Coal Mining Area of the Rhineland], PhD dissertation, University of Cologne.

8. STOLL, R.D., et. al., (eds.) 2009. Der Braunkohlentagebau. Bedeutung, Planung, Betrieb, Technik, Umwelt [Open-cast Lignite Mining. Importance, Planning, Operation, Technology, Environment]. Berlin/Heidelberg, Springer. DOI: https://doi.org/10.1007/978-3-540-78401-2 
9. LOTZMANN, E. 1990. "Territoriale Auswirkungen des großflächigen Braunkohlenbergbaus im Bezirk Cottbus bei besonderer Beachtung der Siedlungsstrukturen" ["Territorial Effects of Large-scale Lignite Mining in the District of Cottbus with a Focus on Settlement Structures"], Informationen zur Raumentwicklung, vol. 4, $\mathrm{n}^{\circ}$ 5: 255-272.

10. UMWELTZENTRUM HOYERSWERDA (ed.), 1990. Verheizte Lausitz. Der Braunkohlenbergbau und seine Probleme im ostelbischen Raum [Burned-out Lusatia. Lignite Mining and its Problems in the Eastern Elbe Region]. Hoyerswerda.

11. BERKNER, A. 1989. "Braunkohlenbergbau, Landschaftsdynamik und territoriale Folgewirkungen in der DDR" ["Lignite Mining, Landscape Dynamics and Territorial Consequences in the GDR"], Petermanns Geographische Mitteilungen, $\mathrm{n}^{\circ}$ 3: 173190.

12. BARTHEL, H. 1965. "Orts- und Teilortsverlegungen in den Braunkohlenrevieren der DDR" ["The Complete or Partial Relocation of Villages in the Lignite Mining Areas of the GDR"], Zeitschrift für den Erdkundeunterricht, vol. 17, n 3: 89-94.

13. LMBV - LAUSITZER UND MITTELDEUTSCHE BERGBAUVERWALTUNGSGESELLSCHAFT MBH (ed.), 2015. Lausitzer Braunkohlenrevier. Wandlungen und Perspektiven 15: Welzow-Süd/Jänschwalde/Cottbus-Nord [Lusatian Lignite District. Changes and Perspectives 15: WelzowSüd/Jänschwalde/Cottbus-Nord]. Senftenberg, LMBV.

14. BALKE, L. et. al., 1993. Ortschronik Wolkenberg [Local Chronicle of Wolkenberg]. Spremberg, Niederlausitzer Heidemuseum.

15. WEBER, E. 1985. "German Democratic Republic: towards the slowing down of territorial concentration in greater urban centres", Espace Populations Sociétés, (special issue "Migrations et urbanisation - Migrations and cities"), vol. $3, n^{\circ} 1$ : 109-118. DOI: https://doi.org/10.3406/espos.1985.1014 